\title{
ПРАВОВЕ ВИХОВАННЯ МАЙБУТНІХ УЧИТЕЛІВ ЯК ОСНОВА ФОРМУВАННЯ В НИХ ТОЛЕРАНТНОГО СТАВЛЕННЯ ДО МАРГІНАЛІЗОВАНИХ ВЕРСТВ СУСПІЛЬСТВА В СИСТЕМІ ОСВІТИ
}

\author{
Петриченко Л. О. \\ доктор педагогічних наук, дочент, \\ професор кафедри педагогіки, психології, початкової освіти та освітнього менеджменту \\ КР «Харківська гуманітарно-педагогічна академія» \\ Харківської обласної ради \\ пров. Руставелі, 7, Харків, Украӥна \\ orcid.org/0000-0002-3250-4321 \\ larisa-petrichenko@ukr.net
}

\author{
Ключові слова: \\ правове виховання, майбутні \\ вчителі, толерантність, \\ маргіналізовані верстви \\ населення.
}

У статті висвітлюється проблема підвищення рівня толерантності сучасного суспільства до маргіналізованих верств населення шляхом організації правового виховання майбутніх вчителів у системі ЗВО.

Мета статті полягає в теоретико-емпіричному вивченні проблеми правового виховання майбутніх вчителів як основи формування в них толерантного ставлення до маргіналізованих верств суспільства в системі освіти, визначенні стану сформованості готовності до толерантної взаємодії майбутніх учителів у ЗВО.

Явище толерантності розглянуто як чесноту правового суспільства, що розкривається у праві всіх його членів бути різними на засадах взаємодії та взаєморозуміння. Проаналізовано низку важливих кроків до встановлення правових основ толерантних відносин у різних сферах українського суспільства, що грунтується на визнанні прав і свобод як найвищої людської цінності та є пріоритетом у питаннях захисту людської гідності й недоторканості.

Проведено педагогічну діагностику реального рівня готовності студентів до толерантної взаємодії ЗВО, для чого розроблено відповідну критеріальну базу, визначено якісний та кількісний склад учасників експерименту, складено методику проведення констатувального експерименту.

Дослідження проведено в Комунальному закладі «Харківська гуманітарно-педагогічна академія» Харківської обласної ради упродовж 2019-2020 н.р. Загальна вибіркова кількість учасників у нашому дослідженні становила 107 осіб - студентів 2-3 курсів різних факультетів академії.

Виявлено, що високий рівень здатності до толерантної взаємодії, що передбачає позитивне ставлення до себе й до іншого, розуміння сутності прав людини, виявлено в небагатьох студентів і студенток - 22,4\%, більшість $(57,9 \%)$ виявили середній рівень здатності до толерантної взаємодії, що передбачає адекватну самооцінку, критичність до себе, але вибіркове ставлення до оточуючих. Певна кількість студентів $(19,7 \%)$ продемонструвала низький рівень здатності до толерантної взаємодії, що виражалося у сформованому стереотипному мисленні щодо маргіналізованих категорій населення. Причиною цього визначена відсутність системи правового виховання майбутніх фахівців, що забезпечує формування в них свідомого ставлення до толерантної взаємодії в освітньому середовищі. 


\title{
LEGAL EDUCATION OF FUTURE TEACHERS AS A BASIS FORMATION OF THEIR TOLERANT ATTITUDE TOWARDS MARGINALIZED LAYERS OF SOCIETY IN THE EDUCATIONAL SYSTEM
}

\author{
Petrychenko L. O. \\ Doctor of Pedagogical Sciences, Associate Professor, \\ Professor at the Department of Pedagogy, Psychology, \\ Primary Education and Educational Management \\ Municipal Establishment "Kharkiv Humanitarian-Pedagogical Academy" \\ of Kharkiv Regional Council \\ Rustavely lane, 7, Kharkiv, Ukraine \\ orcid.org/0000-0002-3250-4321 \\ larisa-petrichenko@ukr.net
}

Key words:

legal education, future teachers, tolerance, marginalized layers of the population.
The article highlights the problem of increasing the level of tolerance of modern society to marginalized layers of the population by organizing the legal education of future teachers in the system of higher educational institutions. The purpose of the article is theoretically and empirically study of the problem of legal education of future teachers as a basis for the formation of their tolerant attitude to marginalized layers of society in the education system; determination of the current state of formation of readiness for tolerant interaction of future teachers in higher educational institutions.

The phenomenon of tolerance is examined as a virtue of a legal society, which is revealed in the right of all its members to be different on the basis of interaction and mutual understanding. It is analysed a number of important steps to establish the legal basis for tolerant relations in various spheres of Ukrainian society, based on the recognition of rights and freedoms as the highest human value and a priority in the protection of human dignity and inviolability. Pedagogical diagnostics of the real level of readiness of students for tolerant interaction of higher educational institutions is carried out, for this purpose the corresponding criterion base is developed, qualitative and quantitative population of participants of the experiment is defined, the technique of carrying out of ascertaining experiment is made.

The study was conducted at the Municipal Establishment "Kharkiv Humanitarian and Pedagogical Academy" of Kharkiv Regional Council during 2019-2020 academic year. The total sample number of participants in our study was 107 people $-2-3$ year students of different faculties of the academy. It was found that a high level of ability to tolerant interaction, which implies a positive attitude to oneself and others, understanding of the essence of human rights, was found in a few students $-22.4 \%$, most $(57.9 \%)$ showed an average level of tolerance, which involves adequate self-esteem, self-criticism, but a selective attitude towards others. There was also a certain number of students $(19.7 \%)$ who showed a low level of ability to tolerant interaction, which was expressed in the stereotypical thinking formed by students about marginalized categories of the population. The reason for this is the lack of a system of legal education of future professionals, which ensures the formation of a conscious attitude to tolerant interaction in the educational environment.
Постановка проблеми. Останнім часом процеси соціальних, економічних, культурних трансформацій стають особливо помітними в Україні, яка зробила свідомий крок до євроінтеграції, кардинального оновлення нормативного законодав- ства, перетворення суспільної свідомості в питаннях визнання рівності прав тих верств населення, які традиційно були маргіналізовані в суспільстві. Необхідно зазначити, що до таких соціальних верств в основному належать громадяни, що не 
можуть повною мірою адаптуватися в соціумі й приносити суспільну користь, потребують підтримки та захисту держави й громади в різних соціальних сферах, якщо йдеться про неповнолітніх, то насамперед у сфері освіти.

Велику значущість проблеми підвищення рівня толерантності сучасного суспільства до маргіналізованих верств населення визначено й концептуальними положеннями Конституції України, міжнародних і вітчизняних законодавчих актів, в яких закарбовано тенденції до демократизації та гуманізації всіх сторін життя сучасного суспільства та системи освіти. Серед таких документів - «Декларація принципів толерантності», Декларація ООН «Про права інвалідів», закони України «Про освіту», «Про вищу освіту», «Про сприяння соціальному становленню та розвитку молоді в Україні», Концепція розвитку інклюзивної освіти тощо.

3 огляду на кардинальну зміну освітніх пріоритетів, підвищуються суспільні вимоги до професійної комунікації вчителів, важливою домінантою підготовки майбутніх педагогічних кадрів стає формування готовності до толерантної взаємодії на засадах глибокого розуміння та поваги до прав і свобод людини в суспільстві. Майбутні вчителі мають спиратися у своїй професійній діяльності на правові основи і норми недискримінаційного спілкування і взаємодії з оточуючими, бути здатними захищати права і свободи учнів та власні. Це передбачає глибоке оволодіння в процесі професійної підготовки майбутнім фахівцем-педагогом знаннями 3 різних галузей права: трудового (умови прийняття, переведення і звільнення 3 роботи, встановлення робочого графіку, охорони праці, відповідальності зокрема щодо неповнолітніх); кримінального (вік настання кримінальної відповідальності, інформація про кримінальне покарання тощо); сімейного (права і обов'язки в родині, форми піклування про дітей і відповідальність батьків чи осіб, які їх замінюють тощо) тощо. Таким чином, толерантність в освітньому середовищі матиме не лише характер особистих переконань та якостей одного конкретного вчителя, а й міцну основу загального орієнтування освітньої діяльності на забезпечення прав і свобод людини, усебічну підтримку незахищених верств населення.

У теорії та практиці вищої освіти накопичено значний досвід, який може стати основою для формування у кваліфікованого фахівця грунтованого на правових знаннях толерантного ставлення до дітей із традиційно маргіналізованих в українському суспільстві соціальних груп (особи 3 інвалідністю, правопорушники, етнічні та релігійні меншини, матеріально незабезпечені тощо). Організація правового виховання студентів забезпечить свідоме виключення із педагогічного спілкування дискримінаційних висловлювань, допо- може уникнути поширення у сфері освіти штампів і стереотипів щодо певних категорій осіб.

Наукові пошуки з вирішення проблеми формування толерантності, зокрема в майбутніх вчителів, посіли центральне місце в науковому доробку зарубіжних та вітчизняних дослідників: Г. Безюлєвої, Я. Берегового, О. Волошиної, Б. Гершунського, О. Гривої, О. Добровіцької, В. Нечерди, С. Рашидова, М. Рожкової, О. Романовського, Г. Солдатової, Н. Уфімцевої, Т. Фадєєвої, Л. Шайгерової, Г. Шеламової та ін.

Методичний аспект формування толерантності в молоді висвітлено О. Асмоловим, Л. Байбородовою, В. Бєляєвим, В. Глєбкіним, Л. Наумовим, Г. Погодіною, М. Рожковим, О. Шаровою, В. Шаліна, О. Щеколдіною та ін.

Аналіз праць дослідників показує, що проблеми формування толерантності сучасної освітянської молоді не можуть бути вирішені без посилення правового виховання студентства у закладах вищої освіти.

Мета статті полягає в теоретико-емпіричному вивченні проблеми правового виховання майбутніх вчителів як основи формування у них толерантного ставлення до маргіналізованих верств суспільства у системі освіти; визначення існуючого стану сформованості готовності до толерантної взаємодії майбутніх учителів у ЗВО.

Виклад основного матеріалу дослідження 3 обгрунтуванням отриманих наукових результатів.

Поняття «толерантність» є порівняно новим в українському науковому дискурсі, його грунтована розробка нараховує дещо більше десятиріччя, а актуалізація пов'язана зі зміною пострадянського суспільства щодо категорій осіб, які традиційно були дискриміновані й сприймалися як «баласт» для суспільства.

Нині український соціум проходить складний шлях від нейтрального ставлення до особливих потреб людини, розуміння переваг людського розмаїття та особливої ролі відмінностей у розвитку держави та громади. Відповідно, змінюється й сприйняття сутності толерантності як важливого суспільного феномена, що віддзеркалює ставлення суспільства до певних категорій населення. Часто в довідковій літературі толерантність тлумачиться як терпимість до чужих думок, вірувань, переконань, поведінки [1, с. 448], терпиме ставлення до чужих позицій [2, с. 274], здатність переносити несприятливий вплив певних чинників, поблажливість [3, с. 1254].

Разом із цим щодо єдності етимологічних позицій щодо сприйняття суті толерантності ми згодні 3 В. Лекторським, який вважає ідею толерантності, хоча і дуже простою на вигляд, насправді доволі складною, що визначається їі 
зв'язком із низкою принципових філософських запитань щодо розуміння людини, iіi ідентичності, встановлення можливостей і кордонів пізнання й порозуміння [4, с. 16$]$.

Нині явище толерантності часто згадується як чеснота правового суспільства, що розкривається у праві всіх його членів бути різними, забезпеченні взаєморозуміння між конфесіями, політичними, етнічними та іншими соціальними групами, вираженні поваги до різноманітності етносів та культур, готовності до колобарації з людьми, що відрізняються зовнішніми ознаками, мовою, поглядами, звичаями і традиціями [6, с. 78].

Важливо підкреслити, що в правовому контексті толерантність визначається як готовність держави та іiі інституцій дозволяти існування альтернативної думки в суспільстві, забезпечувати в межах конституційних норм діяльність опозиції, враховувати потреби громади та окремих її груп, виключати насильство щодо різного роду меншин [6, с. 6].

Вітчизняна вчена О. Добровіцька, досліджуючи проблеми толерантності серед студентської молоді, наголошує, що толерантність передбачає прийняття іншого в різноманітті, відмову від нетерпимості до людини незалежно від ії соціального статусу, майнового стану, стану здоров'я. Толерантність - це не прояв жалю, потурання, поблажливого ставлення, це відмова від власних інтересів, що має проявлятися в активному пошуку спільних поглядів і можливості взаєморозуміння. Толерантне ставлення до іншої людини передбачає визнання та розуміння того, що особистість не просто інша, але і має право бути іншою [5, с. 81-82].

Аналіз останніх кроків української держави в царині розбудови суспільства толерантності та рівних можливостей показує, що Україною здійснено низку важливих кроків до встановлення правових основ толерантних відносин у різних сферах суспільства, що грунтується на визнанні прав і свобод як найвищої людської цінності та є пріоритетом у питаннях захисту людської гідності й недоторканості. Зокрема, в Конституції України, провідні положення якої зорієнтовані на світові стандарти правового забезпечення, повага до прав і свобод людини визнається пріоритетним обов'язком держави (ст. 3). Законом України «Про засади запобігання та протидію дискримінації в Україні» (2012р.) державна політика спрямовується на недопущення дискримінації щодо осіб незалежно від наявності в них дискримінаційних ознак, таких як стать, вік, громадянство, колір шкіри, політичні та релігійні переконання, інвалідність, етнічне та соціальне походження, сімейний та майновий стан, місце проживання, мовні або інші ознаки. У ст. 7 зазначеного Закону заохочуються позитивні дії щодо маргіналізова- них у суспільстві категорій осіб, наголошується на необхідності створення умов для встановлення фактів дискримінації, навіть прихованої, та забезпечення ефективного правового захисту людини. У документі підкреслюється потреба поширити виховання і пропаганду серед населення України поваги до осіб, які традиційно виступали об'єктом дискримінації в суспільстві.

Цілеспрямоване вивчення проблеми правового виховання майбутніх вчителів як основи формування в них толерантного ставлення до маргіналізованих верств суспільства в системі освіти передбачає проведення педагогічної діагностики реального рівня готовності студентів до толерантної взаємодії ЗВО. Для здійснення експериментального дослідження ми розробили відповідну критеріальну базу, визначили якісний та кількісний склад учасників експерименту, склали методику проведення констатувального експерименту. Дослідження проводилось у Комунальному закладі «Харківська гуманітарно-педагогічна академія» Харківської обласної ради упродовж 2019-2020 н.р. Загальна вибіркова кількість учасників у нашому дослідженні становила 107 осіб студентів 2-3 курсів різних факультетів академії, які виявили бажання брати участь у засіданнях клубу толерантності.

У процесі розробки критеріальної бази дослідження ми відштовхувалися від загального визначення поняття толерантності як здатності до прийняття іншого, поваги до людського розмаїття. Критеріями визначення готовності до толерантної взаємодій було вибрано:

- когнітивний (рівень соціальних знань щодо правових аспектів толерантності, розуміння понять «права людини», «дискримінація», «дискримінаційні ознаки», наявність досвіду позитивної взаємодії з маргіналізованими верствами населення), що оцінювався за допомогою методу соціально-педагогічних ситуацій, опитування, методики «Мій Всесвіт»;

- ціннісно-мотиваційний (рівень сформованості цінностей гуманістичного суспільства і вмотивованість до толерантної взаємодіi), що вивчався за допомогою методики діагностики комунікативної толерантності О. Бойко й тесту особистісних конструктів Дж. Келі;

- діяльнісний (вміння проявляти повагу до прав людини і толерантну поведінку в ситуаціях взаємодії з маргіналізованими категоріями населення), дослідження якого забезпечували метод якісних (експертних) оцінок педагогів, тест «Коли я не правий», ігрова методика «Європейський експрес».

Аналізуючи отримані результати, зазначимо, що високий рівень здатності до толерантної взаємодії, що передбачає позитивне ставлення до себе й до іншого, гармонійне самосприйняття й 
сприйняття оточуючих, розуміння сутності прав людини, уникання в комунікації дискримінаційних штампів і стереотипів, виявлено в небагатьох студентів і студенток $-22,4 \%$.

У процесі діагностики опитування, що такі студенти мають широке коло спілкування, велику кількість друзів, однокурсників, осіб, яким вони надають емоційну підтримку.

Сформовані професійні якості демонструють позитивне ставлення молодих людей до розмаїття суспільства, гуманне ставлення до людей. Студенти мають глибоке і грунтовне уявлення про систему правового захисту й гуманістичних цінностей сучасного суспільства й розуміють важливість їх дотримання у системі освіти.

Більшість опитаних студентів $(57,9 \%)$ виявили середній рівень здатності до толерантної взаємодії, що передбачає адекватну самооцінку, критичність до себе, але вибіркове ставлення до оточуючих. Молода людина лише подекуди орієнтується на потреби та думку інших, виявляе посередню здатність до дипломатичності і поваги.

Такий студент має незначний досвід орієнтування в соціальних ситуаціях щодо взаємодії 3 маргіналізованими верствами населення; не завжди вірно визначає емоційні стани інших людей, вибирає недискримінаційні способи контакту з ними й реалізовує їх у процесі взаємодії, не завжди може зрозуміти іншого, прогнозувати його поведінку, визначити власне місце в процесі спілкування. Середньому рівню властива стійка позитивна поведінка майбутніх фахівців щодо різних категорій осіб.

Виявилася й певна кількість студентів, які продемонстрували низький рівень здатності до толерантної взаємодії (19,7 \%), що виражалося у сформованому стереотипному мисленні щодо маргіналізованих категорій населення, негативному ставленні до осіб, які перебувають у складних життєвих обставинах, неадекватності сприйняття їх ролі в суспільстві, низькому рівні знань щодо прав людини в суспільстві й сфері освіти, питань запобігання дискримінації маргіналізованих верств населення.

Моральні установки таких студентів невисокі або слабко виражені, знижені відповідальність i самоконтроль у професійній комунікації. Несформований мотив навчальної діяльності або не збігаються вибір із мотивом. Присутні негативний відгук щодо навчання у ЗВО, незадоволення стосунками $з$ одногрупниками, викладачами, гостро негативне сприйняття оточуючого середовища.

Висновки і перспективи подальших розробок у цьому напрямі. Загалом поглиблене теоретичне та емпіричне вивчання проблеми правового виховання майбутніх вчителів як основи формування в них толерантного ставлення до маргіналізованих верств суспільства в системі освіти показало недостатній рівень здатності майбутніх вчителів до толерантної взаємодії з учнями, що мають певні дискримінаційні ознаки й належать до маргіналізованих верств населення. Причиною цього $\epsilon$, на нашу думку, відсутність системи правового виховання майбутніх фахівців, що забезпечує формування в них свідомого ставлення до взаємодії в освітньому середовищі під час фахової підготовки, а також відсутність у студентів життєвого досвіду спілкування та поводження з різними категоріями осіб.

3 огляду на це перспективним напрямом подальших досліджень $є$ обгрунтування змоги створити у ЗВО систему правового виховання студентів, орієнтовану на їх подальшу професійну самореалізацію та життя в суспільстві рівності і толерантності.

\section{Література}

1. Педагогічний словник / за ред. дійсного члена АПН України М.Д. Ярмаченка. Київ : Педагогічна думка, 2001. 514 с.

2. Соціолого-педагогічний словник / за ред. В.В. Радула. Київ : «ЕксОб», 2004. 304 с.

3. Великий тлумачний словник сучасної української мови / уклад. В. Бусел. Київ : Ірпінь : ВТФ „Перун”, 2004. 1440 с.

4. Лекторский В.А. О толерантности. Философские науки. 1997. № 3-4. С. 14-19.

5. Добровіцька О.О. Підготовка майбутніх соціальних працівників до толерантної взаємодії в умовах інклюзивного середовища : дис. ... канд. пед. наук : 13.00.04. Слов'янськ, 2019. 304 с.

6. На пути к толерантному сознанию / отв. ред. А.. Асмолов. Москва : Смысл, 2000. 255 с.

\section{References}

1. Yarmachenka, N.D. (Ed). (2001). Pedagogical dictionary. Kyiv : Pedagogicheskaya mys1 [in Ukrainian].

2. Radula, V.V. (Ed). (2004). Sociological and pedagogical dictionary. Kyiv : „EksOb” [in Ukrainian].

3. Large explanatory dictionary of the modern Ukrainian language (2004). V. Busel (Ed). Kyiv : Irpin : VTF „Perun” [in Ukrainian].

4. Lektorskiy, V.A. (1997). About tolerance. Filosofskiye nauki. (№ 3-4), 14-19 [in Ukrainian].

5. Dobrovits'ka, O.O. (2019). Preparation of future social workers for tolerant interaction in an inclusive environment. Candidate's thesis. Slovyansk [in Ukrainian].

6. Asmolov, A.G. (Ed). (2000). Towards a tolerant consciousness. Moskva : Smys1 [in Ukrainian]. 